\title{
The Late Holocene upper montane cloud forest and high altitude grassland mosaic in the Serra da Igreja, Southern Brazil
}

\author{
MAURÍCIO B. SCHEER ${ }^{1}$, GUSTAVO R. CURCIO ${ }^{2}$ and CARLOS V. RODERJAN ${ }^{3}$ \\ ${ }^{1}$ SANEPAR, Rua Engenheiros Rebouças, 1376, Rebouças, 80215-900 Curitiba, PR, Brasil \\ ${ }^{2}$ EMBRAPA Florestas, Estrada da Ribeira, Km 111, Caixa Postal 319, 83411-000 Colombo, PR, Brasil \\ ${ }^{3}$ UFPR, Av. Pref. Lothário Meissner, 900, Jardim Botânico, 80210-170 Curitiba, PR, Brasil
}

Manuscript received on July 8, 2011; accepted for publication on June 29, 2012

\begin{abstract}
Many soils of the highlands of Serra do Mar, as in other mountain ranges, have thick histic horizons that preserve high amounts of carbon. However, the age and constitution of the organic matter of these soils remain doubtful, with possible late Pleistocene or Holocene ages. This study was conducted in three profiles (two in grassland and one in forest) in Serra da Igreja highlands in the state of Paraná. We performed $\delta^{13} \mathrm{C}$ isotope analysis of organic matter in soil horizons to detect whether $\mathrm{C}_{3}$ or $\mathrm{C}_{4}$ plants dominated the past communities and ${ }^{14} \mathrm{C}$ dating of the humin fraction to obtain the age of the studied horizons. $\mathrm{C}_{3}$ plants seem to have dominated the mountain ridges of Serra da Igreja since at least 3,000 years BP. Even though the Serra da Igreja may represents a landscape of high altitude grasslands in soils containing organic matter from the late Pleistocene, as reported elsewhere in Southern and Southeastern Brazil, our results indicate that the sites studied are at least from the beginning of the Late Holocene, when conditions of high moisture enabled the colonization/recolonization of the Serra da Igreja ridges by $\mathrm{C}_{3}$ plants. This is the period, often reported in the literature, when forests advanced onto grasslands and savannas.
\end{abstract}

Key words: Atlantic Rain Forest, carbon isotopes, humin fraction, radiocarbon dating, Sea Mountain Range, upper montane vegetation.

\section{INTRODUCTION}

Studies on the vegetation and climate changes during the late Quaternary period are essential for understanding the responses of ecosystems to future climate change (Pessenda et al. 1996a, Scheel-Ybert et al. 2003, Behling 2002).

Although there is increasing knowledge of the subject (Safford 2007), gaps still exist for understanding climate changes in the Brazilian

Correspondence to: Maurício Bergamini Scheer

E-mail:mauriciobs@sanepar.com.br highlands during glacial and interglacial cycles of the late Cenozoic Era, and responses of vegetation to these cycles (Behling and Safford 2009).

The relative dominance of $\mathrm{C}_{3}$ plants (indicator of forests and cool season grasses, usually from more humid areas) or $\mathrm{C}_{4}$ plants (indicator of tropical grasslands, of warm seasons, aquatic plants) (Smith and Epstein 1971, Dümig et al. 2008) in past plant communities can be adequately studied by stable carbon isotopic composition $\delta^{13} \mathrm{C}$ of soil organic matter (Boutton et al. 1998). The $\delta^{13} \mathrm{C}$ values of 
$\mathrm{C}_{3}$ and $\mathrm{C}_{4}$ plant species range between $-34 \%$ and $-24 \%$ (usually around $-27 \%$ ), and $-19 \%$ and $-6 \%$ (-13\%o), respectively (Boutton et al. 1998, Smith and Epstein 1971).

In the last sixty years, ${ }^{14} \mathrm{C}$ analysis has been used in soil studies, in chronological studies and in studies investigating the genesis of organic matter and soil carbon dynamics (Pessenda et al. 1996b). Pessenda et al. (1996b), Gouveia and Pessenda (1999) and Pessenda et al. (2001a) compared different material from similar depths in several soil profiles in the Northern, Southeastern and Southern Brazil. These authors found comparable ages in the charcoal samples and in the humin fraction of soil, whereas the age of "total" soil samples was younger (showing higher ${ }^{14} \mathrm{C}$ ), probably due to a mixture of materials of different ages. The authors explained that rejuvenation of the soil profile may occur because younger carbon contained humic and fulvic acids, with higher mobility than the humin fraction, that can mix with soil material at greater depths. Besides humic and fulvic acids having higher solubility in alkaline solutions, these humic substances have higher polarity and smaller molecular size than the humin fraction. Even though rainfall generally presents slightly higher $\mathrm{pH}$, humic acids have lower solubility under the acidic conditions normally found in tropical soils (Benites et al. 2003). Therefore, if no fragments of charcoal are present in the samples, the humin fraction is probably the best material for ${ }^{14} \mathrm{C}$ dating when the minimum age of the soil organic matter is taken into account (Pessenda et al. 1996b, Gouveia et al. 1999). Soil formation is accompanied by a continuous incorporation of organic matter to the existing carbon pool. Therefore, radiocarbon ages are always more recent than the initial formation of the soil (Dümig et al. 2008). Despite showing lower reactivity than other humic substances, the humin fraction is responsible for aggregation, and in many tropical soils represents the highest humified soil carbon fraction (Benites et al. 2003, Anjos et al. 2008).
Many studies suggest that the occurrence of severe climate change in South America included colder and drier periods during the late Pleistocene and Holocene if, compared to recent years (Martinelli et al. 1996, Pessenda et al. 1996b, Behling and Lichte 1997, Behling and Negrelle 2001, Parolin et al. 2006, Behling 2007, Saia et al. 2008, Behling and Safford 2009). Comparing data in tropical and subtropical regions, Pessenda et al. (1998) suggested that the subtropical regions were drier than the tropical ones during the early and middle Holocene.

According to Safford (2007), the understanding of the last glacial cycle in Eastern South America has contributed to the knowledge of how glacial events affected the distribution of plants in the highlands of Southern and Southeastern Brazil. Temperatures during the late Pleistocene were around 5 to $7^{\circ} \mathrm{C}$ lower than present temperatures (Behling and Lichte 1997, Behling and Negrelle 2001). This means that during that period, the mountain downslopes (in altitudes around 1,200 $\mathrm{m}$ below the ridges - lowland and submontane formations) would have had similar temperatures now found at the top of the mountains. Therefore, it is possible that the highest peaks, like those of the Serra da Mantiqueira (2,800-2,900 m asl), were snow covered at the end of the last glaciation $\left(0^{\circ} \mathrm{C}\right.$ isotherm $)$, exerting great selective pressure on species of high altitude environments (Safford 2007). The frequent climate oscillations during the Quaternary probably resulted in the migration of a great number of species in colonizations, recolonizations, extinctions, and genetic differentiation (Safford 2007). With conditions that were drier and cooler than today, many mountains of Serra do Mar and Serra da Mantiqueira were covered by extensive areas of high altitude grasslands (Behling et al. 2006, Behling 2007, Behling and Safford 2009), and the forests probably remained at low altitudes, mainly in more protected valleys. The only palaeoenvironmental study conducted in the 
upper montane area in Paraná (Behling 2007), at $1,500 \mathrm{~m}$ asl in the Serra do Araçatuba, indicated that only after 2,000 yr BP did humid forest species (e.g. Araucaria, Ilex, Symplocos, Drimys, Myrsine, Weinmannia and Myrtaceae family) start to occupy higher altitudes in the mountains up to a certain limit of expansion, indicating that conditions were wetter.

Continuing the studies of the upper montane environments in Paraná performed by Mocochinski and Scheer (2008), Scheer and Mocochinski (2009), Scheer et al. (2011a, b), and Scheer et al. (2013), the present study was conducted in the high altitude grassland and the upper montane cloud forest of Serra da Igreja, which belongs to the Serra do Mar complex in the state of Paraná. The objective of this study was to investigate how climate changes during the past influenced the occupation of the environment (mountaintop) by native forest and grassland. Therefore, we performed $\delta^{13} \mathrm{C}$ isotope analysis of organic matter in soil horizons to detect whether $\mathrm{C}_{3}$ or $\mathrm{C}_{4}$ plants dominated de past communities and ${ }^{14} \mathrm{C}$ dating of the humin fraction to obtain the age of the studied horizons.

\section{MATERIALS AND METHODS}

STUdy AREA

The study area is located on one of the peaks of the Serra da Igreja, part of Serra do Mar, in the state of Paraná, in Southern Brazil, at 1,335 $\mathrm{m}$ asl $\left(25^{\circ} 36^{\prime} \mathrm{S}\right.$ and $48^{\circ} 51^{\prime} \mathrm{W}$ ) (Fig. 1). Serra da Igreja is part of the Guaratuba Environmental Protection Area in the municipalities of Guaratuba, Morretes and São José dos Pinhais. Like most of the mountains of Serra do Mar in Paraná, their upper portions are formed by alkali granites embedded in high-grade metamorphic terrains with contacts clearly failing in keeping with their late to post tectonic origin (Mineropar 2001). According to Mineropar, intrusive igneous rock from Serra da Igreja originated nearly 550 million years ago in the Late Pre-Cambrian to Cambrian. It was cut by faults in the NE-SW axis by the Brasiliano (or Pan African) Cycle (events of the end of the late
Proterozoic) and the Ponta Grossa Arch (Mesozoic), a major structure in the NW-SE basin of the Paraná river (Melo et al. 2000). The upper parts of Serra da Igreja are covered with natural vegetation (dense rain/cloud forest and grasslands). These high altitude grasslands are located in a summit position with the absence of stony and rocky elements in a gentle relief dominanted by hydric divergence. The upper montane cloud forests occupy the saddles (mountain pass) in strong undulating and mountainous reliefs that are dominated by hydric convergence (Fig. 2).

In this mountain range, the Atlantic Rain Forest covers its greatest extension, reaching the upper montane formation, with the uppermost part of the slopes higher than $1,200 \mathrm{~m}$ asl. This forest is very well preserved due to its isolation and difficult access. In some slopes, located on the occidental side of the Serra do Mar (at about 1,100 m asl), there is an ecotonal zone between the Atlantic Rain Forest and the Montane Araucaria Rain Forest. In the uppermost parts of the mountains, from $1,300 \mathrm{~m}$ asl, the high altitude grasslands start appearing. They are in excellent condition with no signs of human interference.

The sampling points were in a topographical sequence that involves sharp ridges (flat tops at $1,335 \mathrm{~m}$ asl) covered by high altitude grasslands on Histosols (according to World Reference Base for Soil Resources - FAO-WRB) in divergent, convex ramps with small geographic sizing (1.5 ha). After an abrupt change in slope, the landscape gives rise to concave, converging ramps covered by an upper montane cloud forest in Gleysols with a histic horizon (Figs. 1 and 2).

The high altitude grasslands of the study area are composed of herbaceous plants approximately $70 \mathrm{~cm}$ height, in which Lagenocarpus triquetrus (Boeck.) Kuntze (Cyperaceae) is the dominant species, along with small shrubs (average 50 $\mathrm{cm}$ tall) such as Croton mullerianus L. R. Lima (Euphorbiaceae) and Tibouchina dubia (Cham.) Cogn. (Melastomataceae). Tree species composing 


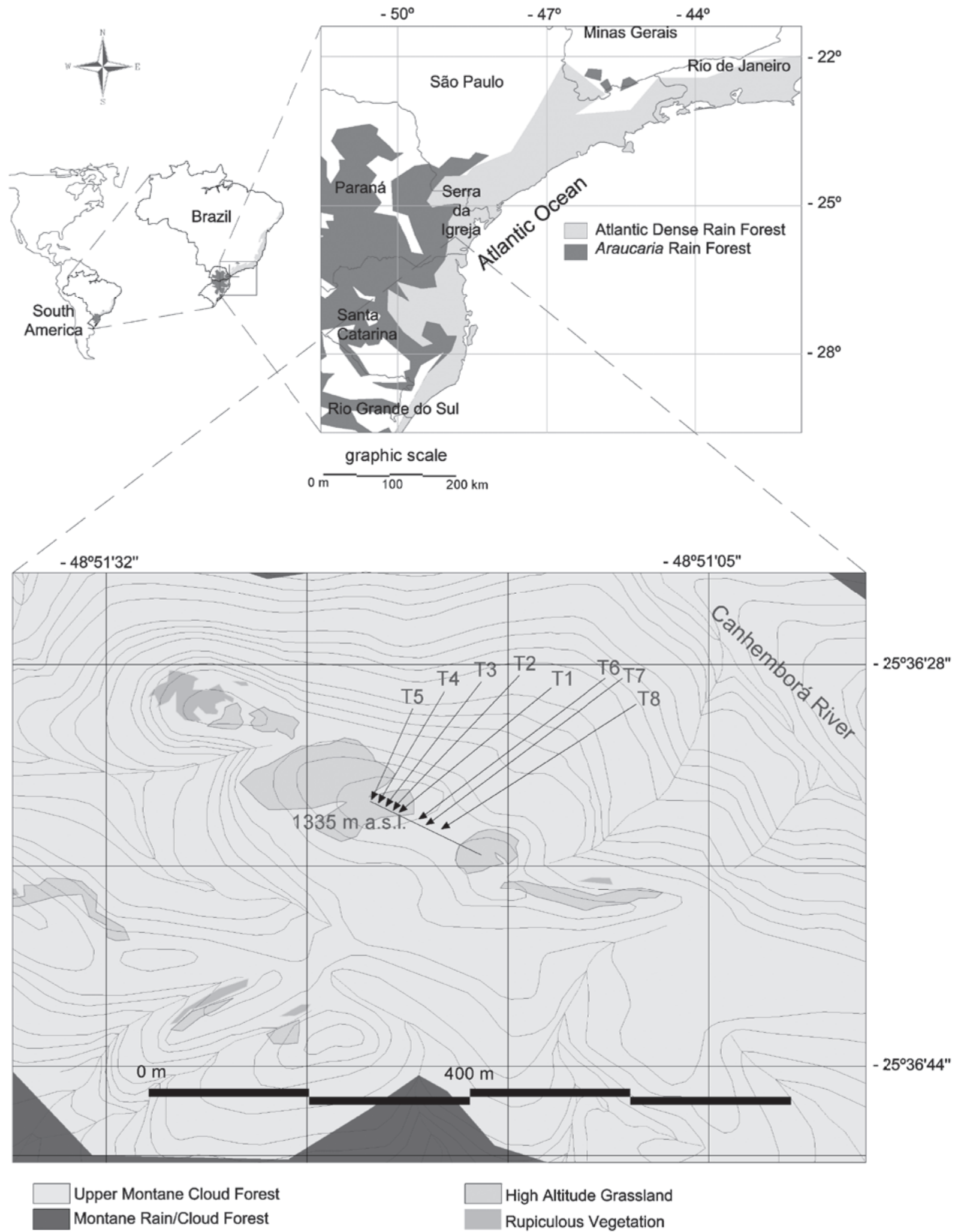

Fig. 1 - Location of the sampled area in Serra da Igreja, Southern Brazil. T = sampling points. 
the adjacent upper montane cloud forest (with height of approximately $5 \mathrm{~m}$ ), including Myrsine altomontana MF Freitas and Kin. Gouvêa (Myrsinaceae) and Tabebuia catarinensis A. Gentry
(Bignoniaceae), occur sparsely in the high altitude grasslands like a shrub with an average height of $50 \mathrm{~cm}$. Mocochinski and Scheer (2008) listed 99 species of vascular plants for these grasslands.

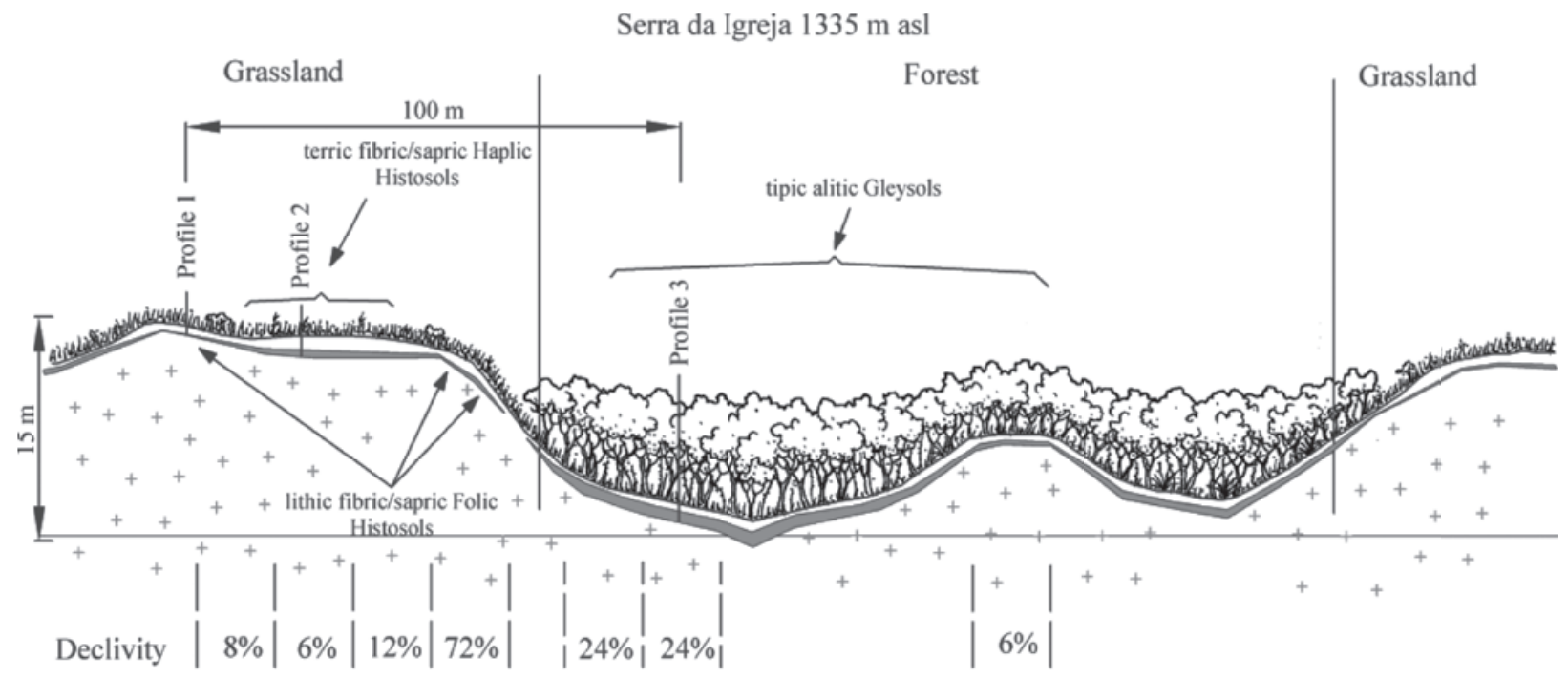

Fig. 2 - Transect with the sampled sites in Serra da Igreja, Southern Brazil.

As described above, the upper montane cloud forests are currently confined by faults belonging to the Brasiliano (or Pan African) Cycle and the Ponta Grossa Arch, allowing such vegetation to reach areas close to the main tops of the mountain range. The change in vegetation from forest to grassland is abrupt and includes an ecotonal area with shrubby physiognomy with species of both formations across a gradient of a few meters (2-5 m). According to Scheer et al. (2011b), Siphoneugena reitzii D. Legrand (Myrtaceae), Ilex microdonta Reissek (Aquifoliaceae) and Drimys angustifolia Miers. (Winteraceae) make up 50\% of the phytosociological importance percentage of trees (Perimeter at breast height - PAP $\geq 10 \mathrm{~cm}$ ). According to the authors, the basal area is $30.5 \mathrm{~m}^{2} /$ ha, and the density is 4,696 trees/ha.

The climate of upper portions of the Serra do Mar of Paraná is classified as Cfb (subtropical), according to the Köppen classification system. It is always wet and the average temperature of the coldest month is between $-3^{\circ} \mathrm{C}$ and $18^{\circ} \mathrm{C}$ and the average temperature of the warmest month is below $22^{\circ} \mathrm{C}$ (Roderjan 1994). Roderjan and Grodski (1999) observed an absolute minimum temperature of $-5^{\circ} \mathrm{C}$, an average annual temperature of $13.4^{\circ} \mathrm{C}$ and an absolute maximum temperature of $30^{\circ} \mathrm{C}$ in upper montane levels at $1,385 \mathrm{~m}$ asl in a forest environment at Morro do Anhangava in the municipality of Quatro Barras, approximately $25 \mathrm{~km}$ north of the Serra da Igreja. The precipitation in Serra do Mar is well distributed throughout the year and varies greatly depending on local topography. Measurements in the coastal region exceed 2,000 $\mathrm{mm}$ per year, and on the slopes of the mountains these values reach 3,500 mm (Maack 2002).

\section{SAMPLE COLLECTION AND DATA ANALYSIS}

After a detailed mapping of the soils (additional information in Scheer et al. 2011a), samples were collected in a transect involving three soil profiles, two in Histosols and one in a Gleysol. As already commented, the Histosols were found in grasslands on the ridge. One of the profiles in 
Histosol was relatively shallow and well-drained located on the top $(1,335 \mathrm{~m}$ asl). The other was located among slight depressions in the ridge, resulting in restricted drainage.

The Gleysol is part of a mountain saddle (mountain pass at 1,325 m asl) and is covered by an upper montane cloud forest located approximately $80 \mathrm{~m}$ away from the other two profiles (Fig. 2).

For $\delta^{13} \mathrm{C}$ analysis and ${ }^{14} \mathrm{C}$ dating, at least $1 \mathrm{~kg}$ of soil was collected from each horizon or sub-horizon identified. The roots and other plant debris were removed by hand. Most of the waste was removed by flotation in $\mathrm{HCl} 0.01 \mathrm{M}$. The soil samples were dried at $60^{\circ} \mathrm{C}$ to constant weight, disaggregated in a porcelain mortar, sieved at 210 $\mu \mathrm{m}$ to reduce the effects of heterogeneity, and again subjected to flotation in $0.01 \mathrm{M} \mathrm{HCl}$ for new waste removal. Approximately $4 \mathrm{~g}$ per sample were taken for $\delta^{13} \mathrm{C}$ analysis (11 samples). About $100 \mathrm{~g}$ of each sample of organic horizons and 1,000 $\mathrm{g}$ of a single mineral horizon were used for the preparation of humin samples.

An adaptation of the acid-alkali-acid method, described by Pessenda et al. (1996a) and by Gouveia and Pessenda (1999) was used for the preparation of soil humin for ${ }^{14} \mathrm{C}$ dating. The procedure was performed in six samples, five organic (histic horizons) and one mineral ( $\mathrm{Cg}$ horizon), and it consisted of the following: (1) acid digestion with at least $0.5 \mathrm{~L}$ of $0.5 \mathrm{M} \mathrm{HCl}$ at $70-80^{\circ} \mathrm{C}$ for $4 \mathrm{~h}$ to digest lightweight material generated in the process of humification; (2) repeated washing with deionized water and discarding the supernatant to adjust the $\mathrm{pH}$ to 4 , in order to eliminate the acidity of the pre-treatment and to eliminate decomposed compounds; (3) reaction of solid waste with $(0.5$ L per extraction) pyrophosphate decahydrate and $0.1 \mathrm{M}$ sodium hydroxide $(\mathrm{pH}=13)$ for at least $36 \mathrm{~h}$ (12 h per extraction) to solubilize humic and fulvic acids; (4) repeated washes with deionized water and discarding the supernatant until the $\mathrm{pH}$ becomes acidic and the supernatant became clear;
(5) hydrolysis of the residue with about $0.5 \mathrm{~L} 3 \mathrm{M}$ $\mathrm{HCl}$ at about $100^{\circ} \mathrm{C}$ for $12 \mathrm{~h}$ to digest organic wastes such as sugars, proteins, and fats and to eliminate contamination by atmospheric $\mathrm{CO}_{2}$; (6) repeated washing with deionized water and discarding the supernatant until reaching a $\mathrm{pH}$ of 3-4; and (7) drying the solid residue at $40^{\circ} \mathrm{C}$ for at least $48 \mathrm{~h}$ followed by a new maceration in a porcelain mortar and new sieving $(210 \mu \mathrm{m})$. Due to the predominant organic characteristics of the material, even after this procedure some root debris remained. Therefore, all samples with the isolated humin were sieved at $105 \mu \mathrm{m}$ and inspected with a magnifying glass and tweezers for later shipment to the laboratory for ${ }^{14} \mathrm{C}$ dating $(0.1 \mathrm{~g}$ of samples from the organic horizon and $30 \mathrm{~g}$ of sample from the mineral horizon).

As complementary information, samples of leaf tissue of two dominant species in the grassland (Lagenocarpus triquetrus and Croton mullerianus) were collected in triplicate for $\delta^{13} \mathrm{C}$ analysis.

$\delta^{13} \mathrm{C}$ isotope ratios of organic material in soil horizons and plant tissues were determined by mass spectrometry of the $\mathrm{CO}_{2}$ by burning the samples in an atmosphere of pure oxygen at $900^{\circ} \mathrm{C}$ at the Stable Isotope Laboratory of the Centre for Nuclear Energy in Agriculture (Centro de Energia Nuclear na Agricultura - CENA) in Brazil. The results for total organic carbon were expressed as the percentage of dry weight. The $\delta^{13} \mathrm{C}$ results were expressed per thousand (\%o) representing the ${ }^{13} \mathrm{C} /{ }^{12} \mathrm{C}$ ratio of samples in relation to the international standard PDB (Belemnitella fossil limestone material found in an American formation of the Cretaceous Pee Dee, North Carolina) (Stuiver and Polach 1977, Alves et al. 2008) standardized in conventional notation $\delta(\%)$, with an analytical precision of $\pm 0.2 \%$.

$\delta^{13} \mathrm{C}(\%)=\left[\left(\mathrm{R}_{\text {sample }} / \mathrm{R}_{\text {standard }}\right)-1\right] \times 1000 ;$ where $\mathrm{R}_{\text {sample }}$ is the ${ }^{13} \mathrm{C} /{ }^{12} \mathrm{C}$ ratio in the sample and $\mathrm{R}_{\text {standard }}$ the ${ }^{13} \mathrm{C} /{ }^{12} \mathrm{C}$ ratio for the international standard (PDB). 
The analysis of ${ }^{14} \mathrm{C}$ fractions of the humin samples were performed at the University of Georgia, in Athens in the United States of America, using the Accelerator Mass Spectrometry (AMS) technique. Ages were expressed in conventional years before present, -BP $(1,950)$, normalized to $\delta^{13} \mathrm{C}$ of $-25 \%$ PDB and calibrated using a confidence interval of $2 \sigma$ (Stuiver and Reimer 1993, Reimer et al. 2004) as well as in percentage of modern carbon.

\section{RESULTS AND DISCUSSION}

\section{ChARACTERIZATION OF THE PROFILES}

The soil depths of the toposequence (Table I) are similar of those found in a detailed mapping of the soils in the Serra da Igreja ridges (Scheer et al. 2011a). These authors presented an average of $54 \pm$ $3.7 \mathrm{~cm}$ depth in 52 sampling points in the same area of this study and therefore are very representative of what is found in these summits, as well as in many other ridges of Serra do Mar. As expected, the concentrations of total organic carbon from the histic horizons were very high (about 45\%, Table I). In these Histosols, there is a predominance of fibric material in the upper layers and sapric material in the lower layers. The organic substrates are related to factors that determine low decomposition rates, such as soil hydromorphy, frequent presence of fog, low temperatures and high atmospheric humidity. Despite showing much lower carbon concentrations than the organic horizons, the mineral horizons also have considerable amounts of this element (between 2.5 and $4.7 \%$ ). The color of these horizons indicate a morphologically reducing environment (10YR $4 / 1$ and 5/3, dark gray and yellowish-brown, respectively) (Table I). Major details about these soil profiles can be found in Scheer et al. (2011a).

$\delta^{13} \mathrm{C}$ OF SOIL ORGANIC MATter

Despite the possibility of important differences in the $\delta^{13} \mathrm{C}$ signature of the soil organic matter, it is assumed that variations smaller than $4 \%$ are associated with isotopic fractionation during decomposition (higher stability of lipids and lignin in relation to compounds enriched in ${ }^{13} \mathrm{C}$, such as hemicelluloses, sugars, pectins and amino acids) and differences in the isotopic composition of atmospheric $\mathrm{CO}_{2}$ (Dümig et al. 2008, Nadelhoffer and Fry 1988, Boutton 1998). Therefore, the range of the $\delta^{13} \mathrm{C}$ signature found in all of the horizons analyzed (2.5\%, Table II and Fig. 3 ) is too narrow to be associated with changes in vegetation in the province of Histosols. However, this probably occurred in the Gleysol profile, currently covered with forest. With the drier conditions of the middle Holocene (Scheel-Ybert et al. 2003, Behling and Safford 2009), this site would probably be a grassland formation, probably supporting some shrubs due to the geomorphic features. However, with increasing humidity during the late Holocene (Pessenda et al. 1996a, Gouveia et al. 1999, Scheel-Ybert et al. 2003), the forest was able to spread. All values could be considered to be depleted in ${ }^{13} \mathrm{C}$, indicating the predominance of $\mathrm{C}_{3}$ plants from its formation to the present date. Thus, according to ${ }^{14} \mathrm{C}$ analysis, in Serra da Igreja, $\mathrm{C}_{3}$ plants seem to have dominated the upper montane areas since at least 3,000 yr BP. This fact is confirmed by the $\delta^{13} \mathrm{C}$ values of $\mathrm{C}_{3}$ species such as Lagenocarpus triquetrus $(-25.8 \%$ ) and Croton mullerianus (-29.3\%), currently dominating high altitude grasslands. Plants of this group $\left(\mathrm{C}_{3}\right)$ are related to wet conditions and generally cool climates (Dümig et al. 2008, Pessenda et al. 2009). As discussed further, the time these soils were formed agrees with the period of increased humidity during the late Holocene.

${ }^{14}$ C ANALYSIS OF HUMIN FraCtion

The ${ }^{14} \mathrm{C}$ dating analyses of the humin fraction of soil organic matter of the three profiles are shown in Table II. As expected in Histosols, the results indicate relatively old humic substances with increasing depth within the profiles, characterizing an upward genesis of this class. However, although the profiles are very similar, the different geomorphic conditions may explain the older age 
TABLE I

Stratigraphy of the Serra da Igreja profiles, Southern Brazil.

\begin{tabular}{|c|c|c|c|c|}
\hline $\begin{array}{l}\text { Vegetation } \\
\text { type }\end{array}$ & Horizon & $\begin{array}{l}\text { Depth. } \\
\text { (cm) }\end{array}$ & Color & Description \\
\hline \multicolumn{5}{|c|}{ PROFILE 1 - LITHIC FIBRIC/SAPRIC FOLIC HISTOSOL } \\
\hline \multirow{3}{*}{ grassland } & $\mathrm{O}$ & $0-23$ & & $\begin{array}{l}\text { Fibric histic horizon, less time under water saturation than the underlying } \\
\text { horizon, with higher permeability, with } 46.2 \% \text { of total organic carbon }\end{array}$ \\
\hline & $\mathrm{H}$ & $23-42$ & 10YR 2/1 & Sapric histic horizon, with $43.2 \%$ of total organic carbon \\
\hline & $\mathrm{R}$ & $42+$ & - & Alkali Granite \\
\hline \multicolumn{5}{|c|}{ PROFILE 2 - TERRIC FIBRIC/SAPRIC HAPLIC HISTOSOL } \\
\hline \multirow{5}{*}{ grassland } & $\mathrm{H} 1$ & $0-19$ & N2/ & Fibric histic horizon, with $43.6 \%$ of total organic carbon \\
\hline & $\mathrm{H} 2$ & $19-37$ & $10 \mathrm{YR} 2 / 2$ & Fibric histic horizon, with $45.4 \%$ of total organic carbon \\
\hline & H3 & $37-48$ & 10YR $3 / 2$ & Fibric/Hemic histic horizon, with $48.4 \%$ of total organic carbon \\
\hline & $\mathrm{H} 4$ & $48-56$ & $10 \mathrm{YR} 2 / 2$ & Sapric histic horizon, with $47.2 \%$ of total organic carbon \\
\hline & $\mathrm{Cg}$ & $56-77+$ & $10 Y R 4 / 1$ & Mineral horizon "C gley", with $2.5 \%$ of total organic carbon \\
\hline \multicolumn{5}{|c|}{ PROFILE 3 - TYPIC ALITIC HAPLIC GLEYSOL } \\
\hline \multirow{4}{*}{ forest } & $\mathrm{O}$ & $0-25$ & $\mathrm{~N} 2 /$ & Fibric histic horizon, with $40.8 \%$ of total organic carbon \\
\hline & $\mathrm{Cg} 1$ & $25-40$ & 10YR 4/1 & Mineral horizon "C gley", with $4.7 \%$ of total organic carbon \\
\hline & $\mathrm{Cg} 2$ & $40-55$ & 10 YR $5 / 3$ & Mineral horizon "C gley", with $2.5 \%$ of total organic carbon \\
\hline & $\mathrm{R}$ & $55+$ & - & Alkali Granite \\
\hline
\end{tabular}

of the histic horizons of profile 1 (very shallow and well drained) when compared to that of profile 2 (relatively deep with slow drainage). In spite of the small distance between the two profiles, the lowest age of the materials making up the horizons of the second profile are probably evidence of a change in water regime in the province of Histosols, which are more recent. There was an increase in the thickness of the province due to the large capacity of organic matter to retain water. This resulted in a gradual increase of histic substrates generated by water logging, at the expense of histic substrates generated by the combination of very low temperatures and frequent fog. Under the high water saturation conditions, it is possible that soil mass flows occurred resulting in the loss of soil from profile 2, which has probably been restored gradually over the centuries. The thickening rates of histic horizons, based on the thickness of the layer divided by the number of years of the dated intervals, were higher in profile 2 (1.68 and 0.13 $\mathrm{mm} / \mathrm{yr}$ ) between 0 and $39.5 \mathrm{~cm}$ and 39.5 and 52 $\mathrm{cm}$ deep, respectively. In profile 1, the values were 0.22 and $0.07 \mathrm{~mm} / \mathrm{yr}$ between 0 and $25 \mathrm{~cm}$ and 25 and $35 \mathrm{~cm}$ deep, respectively. High thickening rates in hydromorphic soils, particularly in profile 2, seem to prevent the advance of forest over grasslands. The high density of fine roots and the organic matrix in grasslands probably could not support the normal development of tree species on the summits that are exposed to strong winds (Scheer et al. 2011a). Between 0 and $32.4 \mathrm{~cm}$ depth, profile 3 (in Gleysol under forest) showed a thickening rate of $0.33 \mathrm{~mm} / \mathrm{yr}$.

\section{LATE Pleistocene}

Although material from this epoch have not been found in the sites studied, it is important to discuss why it occurred. Behling and Lichte (1997) and Behling and Negrelle (2001) estimated that during the last glacial maximum $(27,500-14,500$ yr BP), temperatures were between 5 and $7{ }^{\circ} \mathrm{C}$ cooler than today. Such temperatures would not have allowed 
TABLE II

Radiocarbon dating of humin fraction and soil organic matter (SOM) from Histosols horizons (profiles 1 and 2) and from Gleysol mineral horizon (profile 3).

\begin{tabular}{|c|c|c|c|c|c|c|c|c|}
\hline Profile & Horizon & $\begin{array}{c}\text { Depth } \\
\text { (cm) }\end{array}$ & $\begin{array}{l}\text { Laboratory } \\
\text { number }\end{array}$ & $\begin{array}{l}\text { Percentage of modern } \\
\text { C }(\mathrm{pMC}) \pm 1 \sigma\end{array}$ & $\begin{array}{c}\text { Age } \\
\left({ }^{14} \mathrm{C} \text { yr BP }\right)\end{array}$ & $\begin{array}{l}\text { Age (cal yr } \\
\text { BP), } 2 \sigma\end{array}$ & $\begin{array}{c}\delta^{13} \mathrm{C}(\%) \\
\text { humin }\end{array}$ & $\begin{array}{c}\delta^{13} \mathrm{C}(\% \mathrm{)}) \\
\mathrm{SOM}\end{array}$ \\
\hline 1 (grassland) & $\mathrm{O}$ & $2-8$ & - & - & - & - & - & -26.0 \\
\hline 1 (grassland) & $\mathrm{O}$ & $12-18$ & - & - & - & - & - & -25.7 \\
\hline 1 (grassland) & $\mathrm{H}$ & $22-28$ & $\begin{array}{l}\text { UGAMS } \\
5816\end{array}$ & $86.7 \pm 0.25$ & $1,128 \pm 25$ & $931-1,054$ & -27.5 & -26.6 \\
\hline 1 (grassland) & $\mathrm{H}$ & $32-38$ & $\begin{array}{l}\text { UGAMS } \\
5817\end{array}$ & $91.8 \pm 0.22$ & $2,635 \pm 25$ & $\begin{array}{l}2,509- \\
2,762\end{array}$ & -28.0 & -27.0 \\
\hline 2 (grassland) & $\mathrm{H} 2$ & $7-13$ & - & - & - & - & - & -26.9 \\
\hline 2 (grassland) & $\mathrm{H} 2$ & $25-31$ & $\begin{array}{l}\text { UGAMS } \\
5818\end{array}$ & $100.4 \pm 0.28$ & modern & modern & -26.6 & -25.7 \\
\hline 2 (grassland) & $\mathrm{H} 3$ & $40-46$ & $\begin{array}{l}\text { UGAMS } \\
5819\end{array}$ & $97.0 \pm 0.27$ & $235 \pm 25$ & $148-304$ & -26.5 & -26.0 \\
\hline 2 (grassland) & $\mathrm{H} 4$ & $49-55$ & $\begin{array}{l}\text { UGAMS } \\
5820\end{array}$ & $86.1 \pm 0.25$ & $1,183 \pm 25$ & $963-1,166$ & -27.6 & -25.0 \\
\hline 3 (forest) & $\mathrm{O}$ & $10-16$ & - & - & - & - & - & -27.5 \\
\hline 3 (forest) & $\mathrm{Cg} 1$ & $30-36$ & $\begin{array}{l}\text { UGAMS } \\
5821\end{array}$ & $88.4 \pm 0.25$ & $970 \pm 25$ & 774-913 & -27.9 & -27.4 \\
\hline 3 (forest) & $\mathrm{Cg} 2$ & $45-51$ & - & - & - & - & - & -26.8 \\
\hline
\end{tabular}

UGAMS - University of Georgia; AMS (Accelerator Mass Spectrometry) technique.

high altitude grasslands to establish on large areas of some ridges of the Serra do Mar (Behling 2007, Safford 2007, Behling and Safford 2009). Additionally, short dry periods followed by rainfall might have oxidized the organic matter and caused soil erosion. Some records of the montane and upper montane areas during this period have been reported in Morro do Itapeva in Serra da Mantiqueira (Behling 1997), in Serra da Bocaina (Behling et al. 2007) and in Serra do Mar (Pessenda et al. 2009), both in Southeastern Brazil. Considering the significantly lower temperature at that time, the temperature in the studied areas, which currently has an annual average of $13.4^{\circ} \mathrm{C}$, would be about 6.4 to $8.4^{\circ} \mathrm{C}$. Considering the estimates by Roderjan and Grodski (1999) for Morro Anhangava, similar in altitude and latitude to the sampled environments, show that the studied sites (in Serra da Igreja) would be exposed to average temperatures below $4^{\circ} \mathrm{C}$ at least three months per year, and their estimates show that the studied area would be subject to temperatures lower than $-12^{\circ} \mathrm{C}$.

Soils formed (or being formed) in the period following the last glacial maximum, were not found in this study, probably because the samples were collected from ridges, where soils are shallower and there is a greater loss of sediment. Soils from this period have been observed in Morro dos Perdidos, 1,500 m asl in the Serra do Araçatuba in the South $(14,880$ ${ }^{14} \mathrm{C}$ yr BP) (Behling 2007), in Morro do Itapeva, $1,850 \mathrm{~m}$ asl in the Serra da Mantiqueira $(35,000$ ${ }^{14} \mathrm{C}$ yr BP) (Behling 1997), in the Serra da Bocaina, between 1,500 and 1,650 $\mathrm{m}$ asl $(18,750$ ${ }^{14} \mathrm{C}$ yr BP) (Behling et al. 2007) and in the upper montane regions of the Serra dos Órgãos, 2,010 $\mathrm{m}$ asl $\left(12,380{ }^{14} \mathrm{C}\right.$ yr BP) (Behling and Safford, 2009), in the southeast region of Brazil. Behling and Safford (2009) detected the presence of 


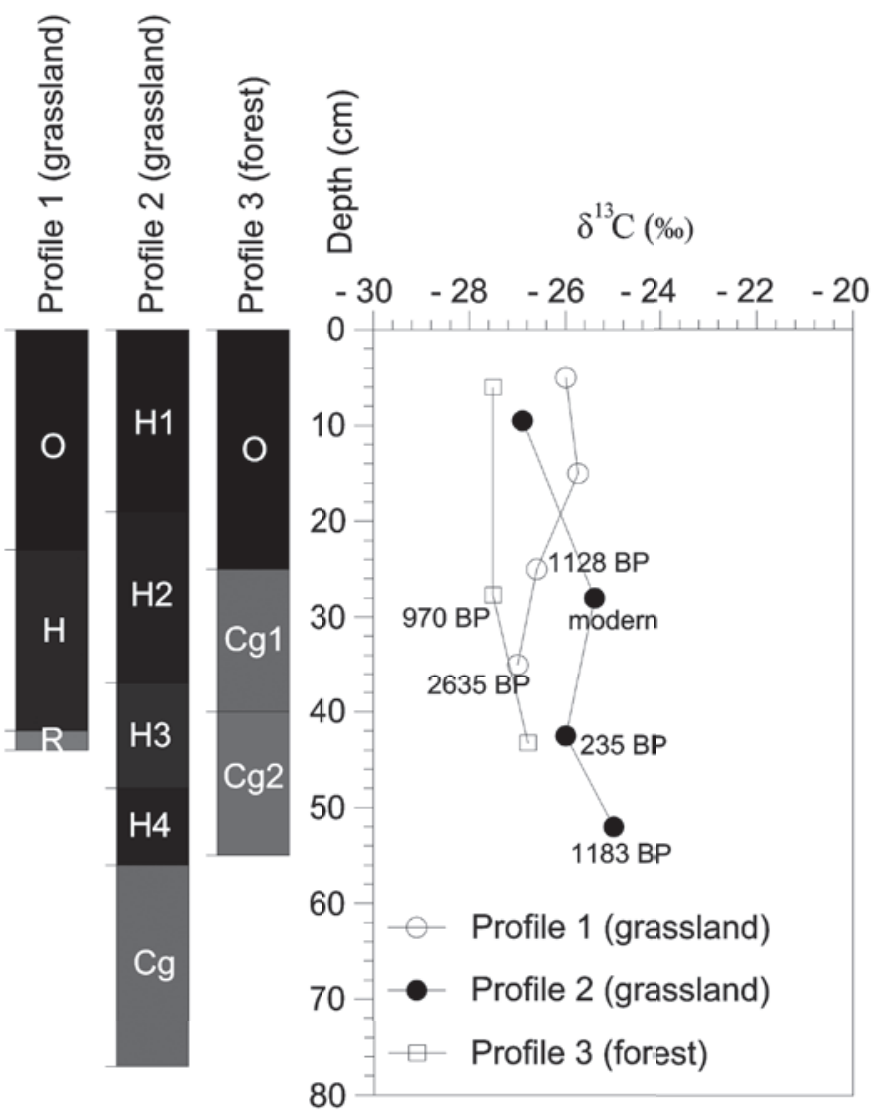

Fig. 3 - Radiocarbon ages of humin fraction and $\delta^{13} \mathrm{C}$ analysis of soil organic matter from profiles in Serra da Igreja, in the state of Paraná, Southern Brazil. (Stratigraphic description is presented in Table I).

upper montane forest probably near the studied site in the Serra dos Órgãos in this period, which correlated to the end of the Younger Dryas. In their study, the authors attributed the short, relatively warm and humid period (similar to the present climate) to the Younger Dryas. This period is related to a periodic reduction of the thermohaline circulation in the North Atlantic Ocean, which resulted in the warming of the tropical Atlantic Ocean (Rühlemann et al. 1999). Evidence of this phenomenon, with intense cooling in the Northern North Atlantic, was also reported by Behling (1997) and Behling et al. (2007) in the Southeast Brazil. However, this phase was not detected at the site studied by Behling (2007) in the Serra do Araçatuba in
Paraná, possibly because this phenomenon was milder in this upper montane region located hundreds of miles further south.

The lack of contemporary dating $(15,000$ to $10,000{ }^{14} \mathrm{C}$ yr BP) in the other mountains studied does not mean that the Serra da Igreja had no high altitude grasslands in its higher regions. It only means that the sampled sites that were situated on the ridges were probably more sensitive to climate change and were exposed to successive colonization and recolonization by vegetation. However, studies including transects with new profiles under forests and grasslands in lower upper montane altitudes in the same mountain, as well as in different geomorphic compartments, such as mountain saddles and slope bases, and in other ridges are needed. 
The coldest and driest periods of the Pleistocene were even less favorable to the expansion and establishment of forests. Behling and Negrelle (2001) revealed the first pollen records of tropical tree species from $14,400{ }^{14} \mathrm{C}$ yr BP in the coastal plain in the state of Santa Catarina in Southern Brazil. Very few pollen from forest species was detected in the higher parts of the Serra do Araçatuba (Behling 2007). In the Serra da Igreja, only the most representative forests would develop at lower elevations, probably as small remnants in protected and moist valleys. However, in the southeast, Pessenda et al. (2009) found records of subtropical forests with conifers between 28,000 and $22,000{ }^{14} \mathrm{C}$ yr BP in positions more toward the top of the lower mountains and in lower latitude compared to the present study, indicating cooler conditions with enough moisture to maintain a mosaic of grasslands and forests.

HOLOCENE

The analysis of the humin fraction of the soil organic matter in the Serra da Igreja indicated that the vegetation is either from the late Holocene or it had its greatest development at least since the beginning of this last period, suggesting that significant changes in climate favored such event.

Similarly, studies performed in the savanna and in the seasonal forests in the midwest and southeast of Brazil suggested that between the early and middle Holocene a drier period prevailed (Scheel-Ybert et al. 2003, Behling and Safford 2009). More humid climate conditions, similar to today, only began between 5,000 and $1,000{ }^{14} \mathrm{C}$ yr BP, depending on the site. In São Paulo (Botucatu, Anhembi and Pirassununga), this shift began to occur around 3,500/3,000 ${ }^{14} \mathrm{C}$ yr BP (Scheel-Ybert et al. 2003), in Jaguariúna after $4,000{ }^{14} \mathrm{C}$ yr BP (Gouveia et al. 1999), in Piracicaba and Londrina after 3,090 ${ }^{14} \mathrm{C}$ yr BP (Pessenda et al. 1996b) and in Mato Grosso do Sul about 4,610/4,010 ${ }^{14} \mathrm{C}$ yr BP (Parolin et al. 2006). After the increase in moisture, most of these sites changed from a predominance of $\mathrm{C}_{4}$ herbaceous vegetation to $\mathrm{C}_{3}$ forest vegetation, in various stages of development, to savanna and seasonal forest. However, the grasslands from the studied sites seem to be dominated by $\mathrm{C}_{3}$ grasses and shrubs indicating subtropical climates. The latitudinal migration of the Intertropical Convergence Zone probably influenced the small variations found among sites mainly in tropical regions, while regions located more to the south of Brazil were under the influence of cold fronts from Antarctica (Behling 2002).

In the Amazon region, between the cities of Porto Velho and Humaitá, the savanna failed to advance over the forest, which has dominated the region since $3,000{ }^{14} \mathrm{C}$ yr $\mathrm{BP}$, because of higher moisture conditions (Pessenda et al. 2001b). The relatively wet condition of that period has been reported in several studies in Southern Brazil (Behling et al. 2001, Behling 2002, Behling 2007, Dümig et al. 2008). Accordingly, since 3,200 ${ }^{14} \mathrm{C}$ yr BP the species present in the Araucaria forest spread through riparian forests, and their significant progress over the grasslands started between 1,000 and $1,500{ }^{14} \mathrm{C}$ yr BP.

Two phases of increased humidity were observed at the end of the Holocene. The first starting at $3200{ }^{14} \mathrm{C}$ yr BP and the second at $1,100{ }^{14} \mathrm{C}$ yr $\mathrm{BP}$ in the state of Santa Catarina. The second was reported in the state of Paraná a little later $(1,400$ ${ }^{14} \mathrm{C}$ yr BP) and then in the Serra do Araçatuba $\left(2,000{ }^{14} \mathrm{C}\right.$ yr BP) (Behling 2007). The ${ }^{14} \mathrm{C}$ analysis of the humin fraction represented by profiles 1 and 2 suggests that they probably started their further development in the first phase. Profile 2 likely progressed in the second phase due to the formation or recover after a possible mass flow, as mentioned previously.

Improved moisture conditions at the late middle Holocene was also reported by Behling and Negrelle (2001), in the Southern coast of Brazil in Itapoá, Santa Catarina. Between 4,330 and 3,190 
${ }^{14} \mathrm{C}$ yr BP, the rainforest of these sites went through a further development after marine regression in $6,000{ }^{14} \mathrm{C}$ yr BP (Behling and Negrelle 2001).

Behling and Negrelle (2001), Saia et al. (2008) and Pessenda et al. (2009) reported the cold climates of the last glacial maximum and the further development of the Atlantic Forest, although probably not very well developed, during the late Pleistocene and early Holocene. Oliveira et al. (2008a) suggested a drier period around 6,000 yr BP. According to Melo et al. (2003), many authors have reported that the south and southeast regions have gone through alternating periods of dry and wet conditions during the late Pleistocene and Holocene, as a result of longerlasting effects of global climate change and shorter events comparable to the El Niño. This climate resulted in the advance of more open vegetation, such as grasslands and savanna, over the forest vegetation in the prolonged annual dry season, but not in the more humid periods (Melo et al. 2003). In some areas, the shrinkage of forests may not have occurred on a regional scale, but was only perhaps a local phenomenon (Martinelli et al. 1996). This rapid environmental change at $4,000{ }^{14} \mathrm{C}$ yr $\mathrm{BP}$, characterized by an increase of precipitation and/ or shortening of the dry season in tropical South America, resulted in opposite conditions in Africa (Marchant and Hooghimstra 2004).

Increased numbers of pollen of grassland species from fields in the Serra dos Órgãos and the presence of charcoal, especially between 9,450 and $7,850{ }^{14} \mathrm{C}$ yr BP, indicate a subsequent dry phase from the early Holocene until about $4,910{ }^{14} \mathrm{C}$ yr BP (Behling and Safford 2009). This is in agreement with studies in areas of savanna and seasonal forest, savanna and Amazon forests and grassland and Araucaria Rain Forest mentioned earlier, when probable conditions of high moisture again led the advance of forests, probably ocurring near the profile studied. In the period preceding the formation of the soils studied by Behling (1997) and Behling (2007) and Safford (2007) (end of the last glacial maximum), climatic conditions were probably dry and cool enough not to result in significant accumulation of organic material on the rock. Although rarer than those reported for the mountain ranges of the southeastern region, in the Serra do Araçatuba, fires occurred in the late Pleistocene, and they were less intense in the early and middle Holocene (Behling 2007), possibly negatively affecting the establishment of vegetation in some areas. The same must have occurred at the site of the present study in the Serra da Igreja, probably in the dry period that extended between the early and middle Holocene.

The peaks of the Serra da Igreja are geomorphic features that during drier periods probably became even less susceptible to recolonization by vegetation in relation to mountain saddles and slopes in the upper montane regions. Such features have comparatively higher moisture, protection and connection with the vegetation located immediately downhill. The driest periods of the early and middle Holocene may also have made the early vegetation susceptible to erosion, possibly worsened by rainy events, leaving most of the ridges free of considerable vegetation. The rupiculous vegetation may be one exception, although probably its establishment occurred more recently.

This possibility agrees with the important events of sedimentation that occurred during these dry periods until the middle Holocene, as documented by Oliveira et al. (2008b). Such events contrasted with periods when seasonal rainfall exceeded evaporation in places near the headwaters in São Bento do Sul, in the state of Santa Catarina. The areas of highest colluviums (profile 3), in the upper montane forest on Gleysol in the Serra da Igreja, allowed the colonization of tree species and made possible the connection with the forests through the advancement of water convergence zones immediately downstream. Therefore, the most high mountain areas of Southern and Southeastern Brazil are likely to have both high altitude grasslands 
established since at least the late Pleistocene and grasslands established or restored on the rock soon after the middle Holocene. From the end of this period, higher humidity conditions allowed a further development (at different intensities) of forest vegetation over the grassland and of grassland on rocky areas of some partially denuded ridges of the Serra do Mar.

Except for this study, all other studies carried out in the upper portions of the mountains of Southern and Southeastern Brazil indicate remnants of more extensive grasslands from late glacial times (Pleistocene) (Behling 1997, Behling 2002,Behling 2007, Behling et al. 2007, Behling and Safford 2009, Pessenda et al. 2009). These studies indicate that the early and middle Holocene were drier and had longer dry seasons than occur presently and that temperatures were relatively warmer in the Holocene than at the end of Pleistocene.

These results highlight the fragility of the soils in the Serra da Igreja as well as other highland soils. Even though weather conditions in the last $3,000{ }^{14} \mathrm{C}$ yr BP have allowed its stability, including an accumulation and increase in the thickness of organic matter, a single event or significant anthropogenic climate change (Flenley 1998, Foster 2001) can transform the upper montane landscape dramatically. This could eventually result in the loss of habitats (forests and grasslands) that serve numerous environmental functions. Considering that mountains are among the regions most affected by climate change (Kohler et al. 2010), more studies and monitoring programs are needed to develop tools to investigate the response of ephemeral, less resilient and primitive ecosystems to future climate change.

\section{CONCLUSION}

The carbon isotope composition and the radiocarbon analysis of the humin fraction of soil organic matter indicate the dominance of $\mathrm{C}_{3}$ plants since at least $3,000{ }^{14} \mathrm{C}$ yr BP in the sites studied in the Serra da Igreja. However, other studies in Southern and Southeastern Brazil indicate the presence of grasslands from the late Pleistocene. It does not mean that the Serra da Igreja had no high altitude grasslands in its upper regions with soil organic matter from this epoch. Because of its topographic position, the ridges of the Serra da Igreja are comparatively more susceptible to climate changes and probably went through several periods of colonization, degradation and recolonization before the establishment of the present vegetation.

Time probably was not the reason why the upper montane forests did not advance over the studied grasslands. Since the beginning of the late Holocene (with wetter conditions), the development of the current upper montane forests have been (up to a limit) under the topographic control of water availability in valleys and saddles, where geomorphic processes are important factors.

Climate change and/or anthropic degradation, which can result in the oxidation of organic matter present in histic horizons, may result in the replacement of grasslands by either forests or successional/ ecotonal areas with low regeneration capacity.

\section{ACKNOWLEDGMENTS}

We would like to thank many colleagues for their substantial help in the field, particularly to Alan Mocochinski and Celina Wisniewski for the first soil samplings in the Serra da Igreja ridges. We also thank Kelly Gutseit for valuable corrections on the manuscript and Fabrício Hansel for the help in the laboratory. We are grateful to many professors and researchers from Universidade Federal do Paraná (UFPR), the Centro de Energia Nuclear na Agricultura (CENA) and the Empresa Brasileira de Pesquisa Agropecuária (EMBRAPA Florestas), for their helpful comments and suggestions. This research was supported by the Fundação Grupo Boticário de Proteção à Natureza (0800_2008_2). We are greatly indebted with Sociedade Chauá and Programa de Pós-Graduação em Engenharia Florestal da UFPR. 


\section{RESUMO}

Muitos solos dos picos da Serra do Mar, como em muitas outras serras, apresentam horizontes hísticos espessos com elevados estoques de carbono. No entanto, a idade e constituição da matéria orgânica destes solos ainda é pouco conhecida e não se sabe se é predominantemente proveniente de comunidades de plantas do final do Pleistoceno ou do Holoceno. Este estudo foi realizado em três perfis, dois em campos altomontanos sobre Organossolos (1.335 m s.n.m) e um em um colo (ponto de sela), onde a floresta altomontana sobre Gleissolos alcança seu patamar mais alto (1.325 m s.n.m). Foram realizadas análises isotópicas $\left(\delta^{13} \mathrm{C}\right)$ da matéria orgânica de horizontes do solo para saber se plantas $\mathrm{C}_{3}$ ou $\mathrm{C}_{4}$ dominaram comunidades vegetais passadas e datações por ${ }^{14} \mathrm{C}$ da fração humina para se saber a idade destes horizontes. Todos os valores de $\delta^{13} \mathrm{C}$ revelaram valores indicativos de plantas $\mathrm{C}_{3}$ (indicativas de florestas e de campos ombrófilos), tanto nos horizontes dos solos do campo quanto nos solos da floresta. Apesar da Serra da Igreja provavelmente apresentar campos altomontanos com material orgânico do solo proveniente do final do Pleistoceno, como em outros estudos no sul e sudeste do Brasil, os sítios estudados, pela sua posição no relevo, são, pelo menos, do Holoceno tardio (3.000 anos AP), quando condições de maior umidade propiciaram a colonização/recolonização das cumeeiras da Serra da Igreja, coincidindo com o período, frequentemente documentado na literatura, de avanço de florestas sobre campos e cerrados.

Palavras-chave: Floresta Ombrófila Densa Atlântica, isótopos de carbono, fração humina, datação por ${ }^{14} \mathrm{C}$, Serra do Mar, vegetação altomontana.

\section{REFERENCES}

Alves BJR, Oliveira OC, Boddey RM AND URQuiaga S. 2008. Métodos isotópicos. In: SANTOS GA ET AL. (Eds), Fundamentos da matéria orgânica dos solos: ecossistemas tropicais e subtropicais. Porto Alegre: Metrópole Editora, RS, BR, p. 229-241.

Anjos LHC, Pereira MG AND Fontana A. 2008. Matéria orgânica e pedogênese. In: SANTOS GA ET AL. (Eds), Fundamentos da matéria orgânica dos solos: ecossistemas tropicais e subtropicais. Porto Alegre: Metrópole Editora, RS, BR, p. 65-86.
BEHLING H. 1997. Late quaternary vegetation, climate and fire history of the Araucaria forest and campos region from Serra Campos Gerais, Paraná State (South Brazil). Review Palaeobot Palyno 97: 109-121.

BEHLING H. 2002. South and southeast Brazilian grasslands during Late Quaternary times: a synthesis. Palaeogeogr Palaeocl 177: 19-27.

BEHLING H. 2007. Late Quaternary vegetation, fire and climate dynamics of Serra do Araçatuba in the Atlantic coastal mountains of Paraná State, southern Brazil. Veg Hist Archaeobot 16: 77-85.

BEHLING H, BAUERMANN SG AND NEVES PCP. 2001. Holocene environment changes in the São Francisco de Paula region, southern Brazil. J S Am Earth Sci 14: 631-639.

BEHLING H, DupONT L, SAFFord HF AND WeFER G. 2007. Late Quaternary vegetation and climate dynamics in the Serra da Bocaina, southeastern Brazil. Quatern Int 161: 22-31.

BEHLING H AND LiCHTE M. 1997. Evidence of dry and cold climatic conditions at glacial times in tropical southeastern Brazil. Quaternary Res 48: 348-358.

Behling H AND NegRelle RRB. 2001. Tropical Rain Forest and Climate Dynamics of the Atlantic Lowland, Southern Brazil, during the Late Quaternary. Quaternary Res 56: 383-389.

BEHLING H AND SAFFORD HD. 2009. Late-glacial and Holocene vegetation, climate and fire dynamics in the Serra dos Orgãos Mountains of Rio de Janeiro State, southeastern Brazil. Glob Change Biol doi: 10.1111/j.13652486.2009.02029.x.

Benites VM, Caiafa AN, Mendonça ES, SchaefFer CEGR AND KER JC. 2003. Soil and vegetation on the high altitude rocky complexes of the Mantiqueira and Espinhaço Mountain. Floram 10(1): 76-85.

BOUtTON TW, ARChER SR, MidwOOD AJ, ZITZER SF AND BOL R. 1998. $\delta^{13} \mathrm{C}$ values of soil organic carbon and their use in documenting vegetation change in a subtropical savanna ecosystem. Geoderma 82: 5-41.

DÜMIG A, Schad P, Rumpel C, DignaC MF AND KÖGELKNABNER I. 2008. Araucaria forest expansion on grassland in the southern Brazilian highlands as revealed by ${ }^{14} \mathrm{C}$ and $\delta^{13} \mathrm{C}$ studies. Geoderma 145: 143-157.

FLENLEY JR. 1998. Tropical forests under the climates of the last 30,000 yr. Climatic Change 39: 177-197.

FOSTER P. 2001. The potential negative impacts of global climate change on tropical montane cloud forests. Earth-Sci Rev 55: 73-106.

GouveIA SEM AND PESSENDA LCR. 1999. Dating of the humin fraction of soil organic matter and its comparison with ${ }^{14} \mathrm{C}$ ages of fossil charcoal. Quim Nova 22(6): 810-814.

Gouveia SEM, Pessenda LCR, Boulet R, ARAVENA R AND SCHEEL-YBERT R. 1999. Carbon isotopes in charcoal and soil organic matter in studies of paleovegetation changes during the Quaternary and the formation rates of soils from the state of São Paulo. An Acad Bras Cienc 71: 4-11.

Kohler T, Giger M, Hurni H, Ott C, Wiesmann U, Von DACH SW AND MASELLI D. 2010. Mountains and climate change: a global concern. Mt Res Dev 30(1): 53-55. 
MAACK R. 2002. Physical Geography of Paraná. Curitiba, Imprensa Oficial, $440 \mathrm{p}$.

MARCHANT R AND HoOghimstra H. 2004. Rapid environmental change in African and South American tropics around 4000 years before present: a review. Earth-Sci Rev 66: 217-260.

Martinelli LA, Pessenda LCR, Espinoza E, CAMARgo PB, TElles EC, CERri CC, Victoria RL, ARAVENA R, RicheY J AND TRUMBO S. 1996. Carbon-13 depth variation in soils of Brazil and relations with climate changes during the Quaternary. Oecologia 106: 376-381.

Melo MS, Giannini PCF and Pessenda LCR. 2000. Genesis and evolution of Lagoa Dourada, Ponta Grossa, PR. Rev Inst Geol 21(1): 17-31.

MELO MS, GIANNINI PCF, PESSENDA LCR AND BRANDT NETO M. 2003. Holocene paleoclimatic reconstruction based on the Lagoa Dourada deposits, southern Brazil. Geologica Acta 1(3): 289-302.

Mineropar - Minerais do PARANÁ S.A. 2001. Atlasgeo.pdf. Geological Atlas of the state of Paraná. Curitiba, p. 116.

MocochINSKI AY AND SCHEER MB. 2008. High altitude grasslands (campos de altitude) on the Serra do Mar Mountain in Southern Brazil: floristic aspects. Floresta 38(4): 625-640.

NADELHOFFER KJ AND FRY B. 1988. Controls on natural nitrogen-15 and carbon-13 abundances in forest soil organic matter. Soil Sci Soc Am J 52: 1633-1640.

Oliveira MAT, Behling H AND Pessenda LCR. 2008a. Late-Pleistocene and mid-Holocene environmental changes in highland valley head areas of Santa Catarina state, Southern Brazil. J S Am Earth Sci 26: 55-67.

Oliveira Mat, Behling H, Pessenda LCR And Lima GL. 2008 b. Stratigraphy of near-valley head quaternary deposits and evidence of climate-driven slope-channel processes in southern Brazilian highlands. Catena 75: 77-92.

Parolin M, Svetlana M and Stevaux JC. 2006. Registros palinológicos e mudanças ambientais durante o holoceno de Taquarussu (MS). Rev Bras Paleontol 9(1): 137-148.

Pessenda LCR, Aravena R, Melfi AJ, Telles ECC, Boulet R, VALENCIA EPE AND TOMAZELlo M. 1996a. The use of carbon isotopes $\left({ }^{13} \mathrm{C},{ }^{14} \mathrm{C}\right)$ in soil to evaluate vegetation changes during the Holocene in central Brazil. Radiocarbon 38: 191-201.

Pessenda LCR, Boulet R, Avarena R, Rosolen V, Gouveia SEM, Ribeiro AS AND LAMOTTE M. 2001b. Origin and dynamics of soil organic matter and vegetation changes during the Holocene in a forest-savanna transition zone, Brazilian Amazon region. Holocene 11(2): 250-254.

Pessenda LCR, Gouveia SEM AND ARAVEnA R. 2001a. Radiocarbon dating of total soil organic matter and humin fraction and its comparison with ${ }^{14} \mathrm{C}$ ages of fossil charcoal. Radiocarbon 43: 595-601.

Pessenda LCR, Oliveira PE, Mofatto M, Medeiros VB, Garcia RJF, ARAVEna R, Bendassoli JA, Leite AZ, SAAD AR AND ETCHEBEHERE ML. 2009. The evolution of a tropical rainforest/grassland mosaic in southeastern Brazil since $28,000{ }^{14} \mathrm{C}$ yr BP based on carbon isotopes and pollen records. Quaternary Res 71: 437-452.
Pessenda LCR, Valencia EPE, Aravena R, Telles ECC AND BOULET R. 1998. Paleoclimate Studies in Brazil Using Carbon Isotopes in Soils. In: Wasserman JC, Silva-Filho EV and Villas-Boas R (Eds), Environmental Geochemistry in the Tropics. Springer, Berlin/New York, v. 72, p. 7-16.

Pessenda lCR, Valencia EPE, Camargo PB, Telles ECC, MARTINElli LA, CERRI CC, ARAVENA R AND ROZANSKI K. 1996b. Natural radiocarbon measurements in Brazilian soils developed on basic rocks. Radiocarbon 38(2): 203-208.

REIMER PJ ET AL. 2004. IntCal04 Terrestrial radiocarbon age calibration, 26 - 0 ka BP. Radiocarbon 46: 1029-1058.

RoDERJAN CV. 1994. Ombrophylous Forest gradient on the Anhangava Hill, Quatro Barras, Paraná, Brazil - climatic, soil and phytosociological features. PhD thesis. Federal University of Paraná, Paraná, Brazil, p. 119.

RoderJan CV ANd GRodski L. 1999. Meteorological monitoring in a Upper Montane Rain Forest environment in Anhangava Hill, Quatro Barras - PR, in the year of 1993. Cadernos da Biodiversidade 2(1): 27-34.

RÜHLEMAnN CR, Mulitza S, MÜLler PJ, Wefer G AND ZAHN R. 1999. Warming of the tropical Atlantic Ocean and slowdown of thermohaline circulation during the last deglaciation. Nature 402: 511-514.

SAFFord HF. 2007. Brazilian Páramos IV. Phytogeography of the campos de altitude. J Biogeogr 34: 1701-1722.

Saia SEMG, PESSENDa LCR, Gouveia SEM, ARAVEna R AND BENDASSOLLI JA. 2008. Last glacial maximum (LGM) vegetation changes in the Atlantic Forest, southeastern Brazil. Quatern Inter 184: 195-201.

ScheEl-Ybert R, Gouveia SEM, PESSEnda LCR, Aravena R, Coutinho LM And Boulet R. 2003. Holocene palaeoenvironmental evolution in the São Paulo State (Brazil), based on anthracology and soil $\delta^{13} \mathrm{C}$ analysis. Holocene 13(1): 73-81.

SCHEER MB, CURCIO G AND RoderJAN CV. 2011a. Environmental functionalities of upper montane soils in Serra da Igreja, Southern Brazil. Rev Bras Cienc Solo 35(4): 10131026.

SCHEER MB, CURCIO G AND RODERJAN CV. 2013. Carbon and water in upper montane soils and their influences on vegetation in Southern Brazil. ISRN Soil Science. doi: $10.1155 / 2013 / 348905$

SCHEER MB AND MOCOCHINSKI AY. 2009. Floristic composition of four tropical upper montane rain forests in Southern Brazil. Biota Neotrop 9(2): http://www.biotaneotropica.org. br/v9n2/pt/abstract?article+bn00609022009 (20/07/2009)

SCHEER MB, MOCOCHINSKI AY AND RODERJAN CV. $2011 \mathrm{~b}$. Tree component structure of tropical upper montane rain forests in Southern Brazil. Acta Bot bras 25(4): 735-750.

SMith BN AND EPSTEIN S. 1971. Two categories of ${ }^{13} \mathrm{C} /{ }^{12} \mathrm{C}$ ratios for higher plants. Plant Physiol 47: 380-384

StUIVER M AND POLACH HA. 1977. Discussion: reporting of ${ }^{14} \mathrm{C}$ data. Radiocarbon 19(3): 355-363.

STUIVER M AND REIMER PJ. 1993. Extended ${ }^{14} \mathrm{C}$ data base and revised CALIB $3.0{ }^{14} \mathrm{C}$ age calibration program. Radiocarbon 35: 215-230. 